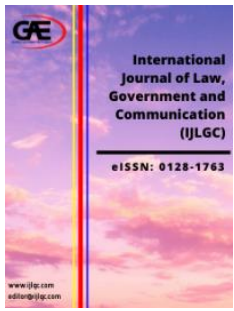

INTERNATIONAL JOURNAL OF LAW, GOVERNMENT AND COMMUNICATION (IJLGC)

$\underline{w w w . i j l g c . c o m}$

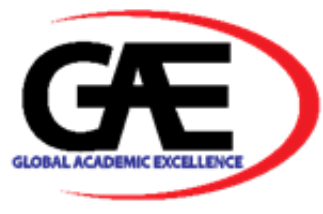

\title{
OVERVIEW OF THE TEMPORARY MEASURES FOR REDUCING THE IMPACT OF CORONAVIRUS DISEASE 2019 (COVID-19) ACT 2020
}

\author{
Rohana Abdul Rahman ${ }^{1 *}$ \\ 1 School of Law, Universiti Utara Malaysia, Malaysia \\ Email: hana@uum.edu.my \\ * Corresponding Author
}

\begin{abstract}
Article Info:
Article history:

Received date: 09.11.2020

Revised date: 15.11 .2020

Accepted date: 10.12 .2020

Published date: 31.12 .2020

To cite this document:

Abdul Rahman, R. (2020). Overview of the Temporary Measures for Reducing the Impact of Coronavirus Disease 2019 (COVID-19) Act 2020. International Journal of Law, Government and Communication, 5 (21), 220-227.
\end{abstract}

DOI: $10.35631 /$ IJLGC.5210017.

This work is licensed under $\mathrm{CC}$ BY 4.0

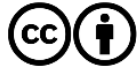

\begin{abstract}
:
The impact of Coronavirus disease has transcended beyond imaginable. Everyone is vulnerable and no one on this planet can safely say that he or she is protected against the deadly virus. All governments are taking immediate steps to address the ensuing repercussion of the pandemic, both on short term and long-term basis. Malaysia has passed a law that provides for temporary measures to reduce the impact of COVID-19 on the general economic sectors affecting the general economic well-being of the country. This paper explains the provisions of the COVID-19 Act 2020 and the specific other laws that it intends to modify therein. In particular, the paper highlights the establishment of a mediation process in respect of disputes arising from the inability to perform contractual obligations by parties during the pandemic. The paper concurs that COVID-19 Act 2020 attempts to cover quite comprehensive temporary measures to address issues relating to the pandemic and in the process provides validity to the actions taken by various parties before its commencement. On the other hand, the paper argues that several vague and uncertain provisions of the law led to questionable application and implication thus creating doubts as to its effectiveness.
\end{abstract}

Keywords:

COVID-19 Act, Pandemic, Temporary Measures, Mediation

\section{Introduction}

When Malaysia detected cases of corona virus disease in February/March 2020, the federal government quickly passed and implemented preventive measure in the form of executive order issued under section 11 Prevention and Control of Infectious Disease Act 1988 termed as the Movement Control Order (MCO). It is also known as lockdown or partial lockdown. Several stages of movement control orders are applicable from March until December 2020. 


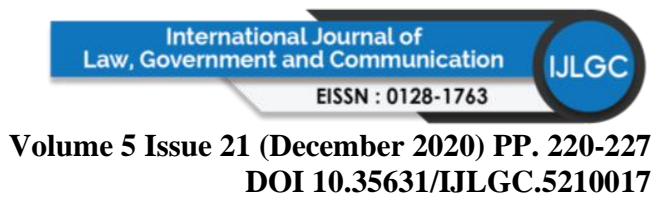

The MCO restricts mass movement and gathering of religious, cultural and social nature, closure of kindergartens, schools, colleges and universities. It also imposes restriction on entry of foreign visitors and tourists via border, airports and ports. Public and private premises are closed except for those involved in essential services such as water, electricity, postal and telecommunication.

These lockdown and restrictions had caused significant economic impacts to the country and to people's livelihood. Businesses were burdened with having to bear their overhead costs while having zero income. Despite the assistance in the form of financial stimulus packages, a large number of struggling businesses could no longer bear their operating costs having no choice but to close down and cease operations. As at November 2020, it was reported that a total of 32,469 small and medium enterprises have closed down since March 2020 due to MCO and COVID-19 pandemic effects (The STAR, 2020).

After consulting various stakeholders, the government has passed a law to provide measures affecting the businesses and modify several laws closely related to businesses. This paper discusses the newly gazetted 'The Temporary Measures for Reducing the Impact of Coronavirus Disease 2019 (COVID-19) Act 2020' (hereinafter referred to as 'COVID-19 Act 2020) and its application.

The following section outlines the enactment, application and content of the statute in general. First, the discussion focus on the general enactment and application of the COVID-19 Act 2020. Second, deliberation follows the arrangement of the Parts to the statute; highlights the most anticipated provision i.e. the legal protection afforded for inability to perform contractual obligation. Then, follows a cursory examination on the different laws modified by the statute. Finally, the paper develops a tentative conclusion at the end.

\section{COVID-19 Act 2020}

The Temporary Measures for Reducing the Impact of Coronavirus Disease 2019 (COVID-19) Act 2020 was first passed in Dewan Rakyat on 25 August 2020 and 22 September 2020 in the Dewan Negara. The law then received royal assent on 16 October 2020 and published in the Gazzete on 23 October 2020. COVID-19 Act 2020 comes into force on the date of publication in the Gazette.

There has been criticism from the business sector of the delay in passing the statute where legal certainty of the existing contractual obligations and business transactions are at stake. According to the government, the delay was inevitable as it had to engage and consult with various stakeholders to provide comprehensive temporary protection measures.

The COVID-19 Act 2020 will be in operation for two years from 23 October 2020 except where provided otherwise in the statute. The Prime Minister may, by order published in the Gazette, extend the operation of the Act. Such extension order can be made more than once.

In general, the COVID-19 Act 2020 has retrospective effect i.e. it provides a 'moratorium' from 18 March 2020 until 31 December 2020. During this 'moratorium' parties affected by the prescribed measures of COVID-19, are restricted from imposing their rights against each other. It has to be noted that several parts of COVID-19 Act 2020 require different length of 'moratorium' period tentatively. 


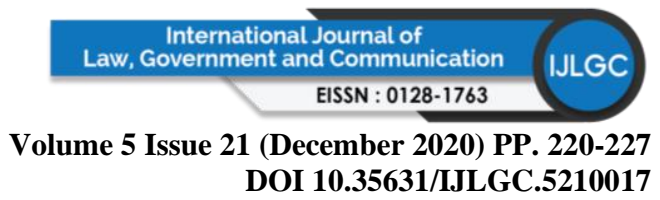

According to section 2 of COVID-19 Act 2020, the Act seeks to modify 16 pieces of legislation (14 Acts of Parliament and 2 Ordinances). The statutes are the Limitation Act 1953 [Act 254], the Sabah Limitation Ordinance [Cap. 72 (1952)], the Sarawak Limitation Ordinance [Cap. 49 (1958 Ed.)], the Public Authorities Protection Act 1948 [Act 198], the Insolvency Act 1967 [Act 360], the Hire-Purchase Act 1967 [Act 212], the Consumer Protection Act 1999 [Act 599], the Distress Act 1951 [Act 255], the Housing Development (Control and Licensing) Act 1966 [Act 118], the Industrial Relations Act 1967 [Act 177], the Private Employment Agencies Act 1981 [Act 246], the Land Public Transport Act 2010 [Act 715], the Commercial Vehicles Licensing Board Act 1987 [Act 334], the Courts of Judicature Act 1964 [Act 91], the Subordinate Courts Act 1948 [Act 92] and the Subordinate Courts Rules Act 1955 [Act 55]. Each modification has been arranged in a specified manner and put in several parts in the statute.

Accordingly, section 3 of COVID-19 Act 2020 provides that the provisions in COVID-19 Act 2020 prevails over any other written law in the event of any conflict or inconsistency. This ensures the ultimate reference of COVID-19 Act 2020 as the oversight law guaranteeing temporary measures during the pandemic.

\section{Inability to Perform Contractual Obligation}

Section 7 of the COVID-19 Act 2020 provides that the inability of any party or parties to perform any contractual obligation under the contracts due to the COVID-19 measures made or taken under the Prevention and Control of Infectious Diseases Act 1988 will not prejudice such party or parties. The law protects the parties where neither party can exercise his or their rights under the contract. There are seven categories of contracts as specified in the Schedule to this Part (Part II).

The list of categories of contracts are: [1] the construction work contract, construction consultancy contract and any other contract related to the supply of construction material, equipment or workers; [2] performance bond granted pursuant to a construction contract or supply contract; [3] professional services contract; [4] lease or tenancy of non-residential immovable property; [5] event contract for the provision of venue, accommodation, amenity, transport, entertainment, catering or other goods or services related thereto; [6] contract by a tourism enterprise (Tourism Industry Act 1992) and contract for promotion of tourism in Malaysia; [7] religious pilgrimage-related contracts.

Looking at the specified categories of contracts, the law speaks directly to the construction industry. The works construction is one of the worst industries affected by the COVID-19 and the MCO. The other industry heavily affected is the tourism industry.

Contracts relating to construction industry are complex and may involve many different parties.

In a normal contract scenario, inability to perform contractual obligations may be subject to the existing terms of the contract. However, by virtue of the above new provision, such neglect by one party will not be a reason for the other party to enforce his right in the contract. Upon scrutiny of the above section 7 , it appears that the wordings are very general in nature and the phrase 'due to the COVID-19 measures' needs unpacking for better application of the law.

The category of professional services contract is not elaborated in the Act. The law appears to allow for wide definition of the 'category of professional services contract'. It is argued that 'professional services' include the services rendered by those in the legal, accounting, Copyright (C) GLOBAL ACADEMIC EXCELLENCE (M) SDN BHD - All rights reserved 


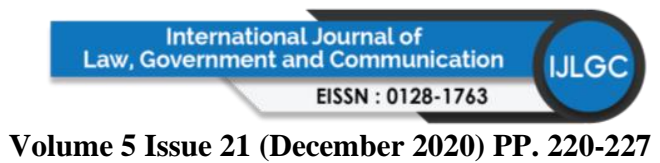

DOI 10.35631/IJLGC.5210017

engineering, architectural, surveying, medical and dental services. Absence of such elaboration may create loophole in the application of the law.

Another type of service missing from the list is the employment service or contracts. It appears that the law acknowledges only 'professional services' and purportedly leaves out the general employment services. The underlying assumption is that employers and employees must all stick to their existing contractual obligations under their employment contracts and may not be subject to the new law.

However, the above list may not be exhaustive. Section 8 of the Act gives power to the Minister to amend the Schedule by order published in the Gazette. The categories of contract may include other type of contracts if need arise.

Despite the above protection, section 10 of the Act provides the saving clause where any contract terminated, any deposit or performance bond forfeited or any damages received from 18 March 2020 until the date of publication of the Act (23 October 2020) shall be deemed to have been validly terminated, forfeited or received.

Part II also provides for an alternative dispute settlement mechanism in the form of mediation. According to section 9 of the Act any dispute in respect of inability to perform contractual obligation arising from any of the stated contracts may be settled by way of mediation. The Minister may determine the mediation process including the appointment and role of mediator as well as conduct and conclusion of the mediation.

Once an agreement is reached by way of mediation, the disputing parties shall enter into a settlement agreement, in writing and signed by both parties. The mediator shall authenticate the settlement agreement and make copies for the parties. Such settlement agreement shall be binding on the parties. These mediation procedures are in line with the provisions of the Mediation Act 2012.

Upon coming into force of the COVID-19 Act 2020, the government has set up a COVID-19 Mediation Centre under the Prime Minister's Office as required under the law. The Centre may have jurisdiction to hear contractual dispute involving less than RM300,000 and below. The mediation service is open for eligible individuals in the B40 and M40 categories, and micro and small scale enterprises. The government would bear the cost of mediation by the eligible groups if done through the Centre for a period of one year from 1 October 2020 to 30 September 2021.

It is noted that the saving clause under section 10 also applies in the case of any legal proceeding, arbitration or mediation commenced, any judgment or award granted or execution carried out for the period from 18 March 2020 until 23 October 2020 (publication date of the Act) shall be deemed to have been validly commenced, granted or carried out.

\section{Legislation Modified by COVID-19 Act 2020}

As mentioned above, 14 Acts of Parliament and 2 Ordinances have been modified by the COVID-19 Act 2020, deemed to have come into operation on 18 March 2020 and shall continue operation until 31 December 2020. COVID-19 Act 2020 takes into account the existing limitations period specified in various laws including Limitation Act 1953 [Act 254] (Part III of COVID-19 Act 2020), the Sabah Limitation Ordinance [Cap. 72 (1952)] (Part IV), 


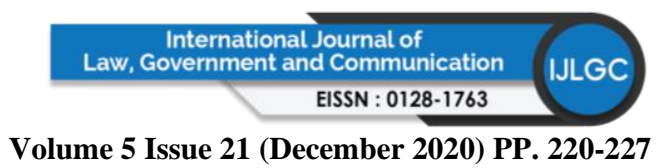

DOI 10.35631/IJLGC.5210017

the Sarawak Limitation Ordinance [Cap. 49 (1958 Ed.)] (Part V) and the Public Authorities Protection Act 1948 [Act 198] (Part VI). The effect of modification allows the expiry of statutory limit to extend until 31 December 2020.

Unlike the other parts of the new law which carries a retrospective effect, Part VII of COVID19 Act 2020 providing for modification to the Insolvency Act 1967, comes into operation on 23 October 2020 and continues operation until 31 August 2021. The significant modification relates to the amount of indebtedness required prior to presenting a bankruptcy petition which has been increased to RM 100,000.00. Before the modification, the amount of indebtedness is RM 50,000.00. On the other hand, any proceeding or action under the Insolvency Act 1967 which has been pending immediately before 23 October 2020 shall be dealt with as if the Insolvency Act 1967 has not been modified by COVID-19 Act 2020.

Part VIII of COVID-19 Act 2020 modifies the Hire-Purchase Act 1967 to be deemed in operation from 1 April 2020 until 31 December 2020. Section 16 of the Hire-Purchase Act 1967 provides for the requirement to give notice to the hirer in the event of a repossession of goods by the owner. Under the new law, an owner shall not exercise his right to repossess goods or vehicles for any default of paying instalment during the period between 1 April 2020 and 30 September 2020. However, owners who have repossessed the goods or vehicle before 23 October 2020 shall be deemed to have validly exercised the right of repossession.

The new law also modifies the Consumer Protection Act 1999 (CPA) in respect of with provisions relating to default in instalment payments under a credit sale agreement and the limitation period to bring a claim to the Tribunal for Consumer Claims.

Previously, section 24V of the CPA allows credit facility providers to recover total outstanding amounts payable under a credit sale agreement through legal proceedings where (a) the debtor has defaulted in payment for two consecutive installments; and (b) the debtor has subsequently failed to pay the overdue amounts, make early settlement or terminate the credit sale agreement.

Under the new law, the debtor may elect to pay the overdue (at least two consecutive) installments to the credit facility provider within 21 days after receiving the notice by the credit facility provider, or make early settlement by paying total amount payable under the credit sale agreement or terminate the agreement and return the purchased goods to the credit facility provider according to law. However, if the debtor fails to carry out any of the actions above, the credit facility provider shall not commence any legal proceedings to recover the total outstanding amount payable by the debtor under the credit sale agreement.

As understood under Section 99(2) of the CPA, the jurisdiction of the Tribunal for Consumer Claims is limited to a claim based on a cause of action accruing within three years of such claim. The new law modifies any period of limitation which has expired between 18 March 2020 to 15 June 2020 to be extended to 31 December 2020.

Further under Part X, COVID-19 Act 2020 modifies Section 5(1) of the Distress Act 1951 whereby a warrant of distress issued for the recovery of rent due or payable to the landlord by a tenant of any premises, will not include the distrain for arrears of rent owing for the period between 18 March 2020 and 31 August 2020. The new law does not affect any warrant of distress issued before the date of publication of the COVID-19 Act 2020. 


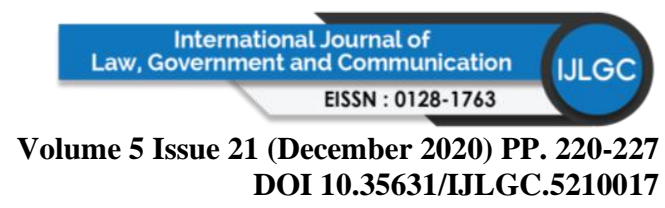

Part XI of COVID-19 Act 2020 modifies the Housing Development (Control and Licensing) Act 1966, deemed to have come into operation on 18 March 2020 and applicable to all agreements for the sale and purchase of housing accommodation in the forms prescribed in Schedules G, H, I and J of the Housing Development (Control and Licensing) Regulations 1989 entered into before 18 March 2020.

Specifically, the new law relates to three significant items namely: late payment charges; delivery of vacant possession and liquidated damages; and defect liability period. It appears that house buyers are protected against late payment charges and permitted to exclude the period between 18 March 2020 and 31 August 2020 from calculation of delivery of vacant possession and liquidated damages; and defect liability period.

In the event, any late payment charges or liquidated damages that has been paid by a house buyer or the developer before the date of publication of the COVID-19 Act 2020, such payment is deemed to have been validly paid under the law and cannot be refundable to the payer.

The new law also permits a homebuyer to file a claim with the Tribunal for Homebuyer Claims from 4 May 2020 to 31 December 2020 in the event the limitation period of 12 months expires during the period from 18 March 2020 to 9 June 2020. It is noted that under the previous section 16N (2) of the Housing Development (Control and Licensing) Act 1966, a homebuyer may file a claim with the Tribunal for Homebuyer Claims not later than 12 months from date of issuance of the certificate of completion and compliance or the expiry date of the defects liability period or the date of termination of the sale and purchase agreement by either party.

Part XII and Part XIII provide for the exclusion of period for important provisions under Industrial Relations Act 1967 and the Private Employment Agencies Act 1981. In particular, in relation to according recognition or notifying the trade union of workmen of the grounds, in writing, for not according such recognition; the making of a written report to the Director General for Industrial Relations and the filing of representation (i.e. to be reinstated on grounds of dismissal without just cause and excuse). In these situations, the computation of statutory limitation periods excludes the period from 18 March 2020 to 9 June 2020. On the other hand, the new law excludes the calculation of the above-mentioned period for application to renew a license for private employment agencies. This exclusion should give a breather to the parties concerned.

Further, Part XIV and Part XV state that the commencement of modification to the Land Public Transport Act 2010 ("LPTA") and the Commercial Vehicles Licensing Board Act 1987 ("CVLBA") shall be effective from 1 August 2020 until 31 December 2021. The modification speaks about temporarily allowing change of use of public service vehicles, tourism vehicles and goods vehicles during the effective period or 12 months. Thus any licensed operator may apply to use the vehicle for the purpose of public service vehicles, tourism vehicles and goods vehicles of any other class. As for the commercial vehicles under the purview of CVLBA, such licensed operator may apply to use the vehicles (both ' $C$ ' vehicle and ' $A$ ' vehicle) for the purpose of public service vehicle or goods vehicle of any other class.

There are three legislations in respect of the business of the courts which have been modified by the new law. The effects of these modifications are that the provisions in the rules of court may be modified or its application may be suspended. 


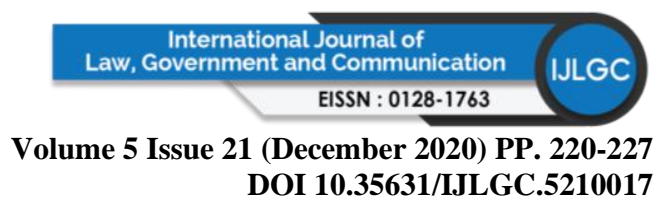

Part XVI in relation to Court of Judicature Act 1964 (CJA) wherein a new section 16A is inserted which confers the general power of the Chief Justice to issue any direction to the business of the Court, if necessary, in the interest of dispensation of justice, public safety, public security, public health or propriety or other sufficient reason to do so (Section 50 of the COVID-19 Act 2020). Another new section 17(3A) is inserted to provide that the Chief Justice may order for alternative arrangement of meetings where any meeting is not possible to be convened, held or conducted (Section 51 of the COVID-19 Act 2020) and following that a new section 17(8) is also inserted to provide that the Chief Justice may, if the circumstances warrant and if it is necessary modify any provision of the rules of court or suspend the application of such rules of court as is necessary for doing complete justice in any cause or matter pending before the Courts and to ensure that the administration of justice is carried out. It is also noted that section 17A of CJA is modified where it is not necessary for Council of Judges to hold at least one meeting in each year (Section 52 of the COVID-19 Act 2020).

Part XVII and Part XVIII provide for modification to the Subordinate Courts Act 1948 (SCA) and Subordinate Courts Rules Act 1955 (SCRA). The provisions modified in SCA and SCRA mimic the modification in CJA conferring the general power of the Chief Justice to issue direction thereto, if necessary, in the interest of dispensation of justice, public safety, public security, public health or propriety or other sufficient reason to do so (as provided in section 53 - 56 of the COVID-19 Act 2020).

The final Part XIX of the COVID-19 Act 2020 allows the Minister charged with the responsibility for any Act, to extend the time for the [A] authority to perform its statutory duties or obligations as well as provide for alternative arrangements in the event any statutory duty or obligation is not possible to be performed or any statutory meeting is not possible to be convened, held or conducted in the manner provided in such Act. This is applicable during the period from 18 March 2020 to 9 June 2020 due to the measures prescribed, made or taken under the Prevention and Control of Infectious Diseases Act 1988. The law also states that no [A] authority is liable for any damages in respect of failure to perform any duty or obligation within the time stated in such Act.

\section{Conclusion}

Based on the above overview of the COVID-19 Act 2020, it seems that the new law attempts to cover quite comprehensive measures albeit temporary in order to cushion the overwhelming effects of the COVID-19 pandemic and the MCO. Its enactment has to be applauded as it has now provided the much-needed assurance relating to the validity of actions taken by various parties before its commencement. Having said that, in some places though, the Act seems to be vague and uncertain making its applications and implications somehow unpractical; and in consequent breeds doubts as to its effectiveness in overcoming issues caused by COVID-19 pandemic in Malaysia.

\section{Reference}

Bailey, J., Bouchardie, N. \& Ignacio, M. (2020, April 14). COVID-19: The Current Impact on Construction and Engineering Projects. Retrieved from https://www.whitecase.com/publications/alert/COVID-19-current-impactconstruction-engineering-projects (accessed on 20 July 2020)

Carvalho, M., Hemananthani Sivanandam \& Rahimy Rahim. (2020, August 25). Dewan Rakyat Passes Temporary Measures Bill for COVID-19, Modifies 16 Legislations. The STAR. Retrieved from https://www.thestar.com.my/news/nation/2020/08/25-dewan- 


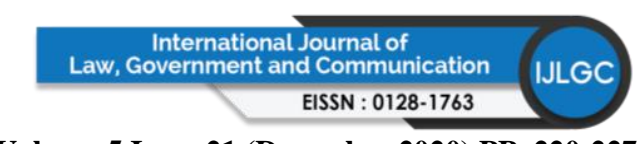

Volume 5 Issue 21 (December 2020) PP. 220-227

DOI 10.35631/IJLGC.5210017

rakyat-passes-temporary-measures-bill-for-COVID-19-modifies-16-legislations (accessed on 26/10/2020)

Carvalho, M., Hemananthani Sivanandam \& Rahimy Rahim. (2020, August 25). Special Mediation Centre to be Set Up to Help Resolve Covid-19 Related Contractual Disputes. The STAR. Retrieved from https://www.thestar.com.my/news/nation/2020/08/25/special-mediation-centre-to-beset-up-to-help-resolve-covid-19-related-contractual-disputes (accessed on 26 October 2020)

Loulakis, M.C. \& McLaughlin, L.P. (2020). The Law: Construction Industry Impacts in the COVID-19 World. Retrieved from https://news.asce.org/the-law-constructionindustry-impacts-in-the-covid-19-world/ (accessed on 20 July 2020)

National Home Buyers Association. What is the impact of COVID-19 on Malaysia's construction industry and what can be done? Retrieved from https://www.iproperty.com.my/news/COVID-19-impact-malaysia-constructionindustry-what-can-be-done/ (accessed on 20 October 2020)

Shannon Rajah \& Jocelyn Lim. Malaysia: COVID-19: Construction Projects - What you need to know and what you can do now. Retrieved from https://www.ilo.com (accessed on 28 July 2020)

Teh Tai Yong. (2020, April 11). Malaysia needs to enact a COVID-19 law to help the economy to recover. The STAR. Retrieved https://www.thestar.com.my/opinion/letters/2020/04/11/malaysia-needs-to-enact-acovid-19-law-to-help-the-economy-to-recover (accessed on 19 July 2020)

(2020, August 25). Temporary Measures Bill for COVID-19 Delayed Due to Planning Process, Says Minister. Retrieved from https:www.malaymail.com/news/malaysia/2020/08/25 (accessed on 20 October 2020)

Tarrence Tan, Hemananthani Sivanandam \& Rahimy Rahim (2020. November, 9). Over 30k SMEs have shuttered since the beginning of MCO, Parliament told. The STAR. Retreived from https://www.thestar.com.my/news/nation/2020/11/09/over-50k-smeshave-shuttered-since-the-beginning-of-mco-parliament-told (Accessed on 9 November 2020) 